\title{
ANALISIS PENERAPAN SISTEM RAINWATER TANK DI PERUMAHAN CITRA INDAH BATAM CENTER
}

\author{
Ade Jaya Saputra ${ }^{1)}$, Priscillia Fu ${ }^{1)}$ \\ ${ }^{1)}$ Fakultas Teknik Sipil dan Perencanaan, Universitas Internasional Batam \\ Sei Ladi, Jl. Gajah Mada, Baloi Permai, Sekupang, Batam, Kepulauan Riau \\ Corresponding author: ade.jaya@uib.ac.id
}

\begin{abstract}
Abstrak
Perkembangan penduduk di kota Batam mengakibatkan peningkatan frekuensi terjadinya banjir. Penelitian ini bertujuan untuk mengetahui perencanaan serta jumlah air dan biaya yang dihemat dengan system rainwater tank untuk kawasan perumahan Citra Indah, Batam Center. Penelitian ini menganalisis kebutuhan tanki yang diperlukan untuk 4 tipe rumah di perumahan Citra Indah. Data perumahan diperoleh dari PT Bangun Arsikon Batindo dan data curah hujan dari Badan Meteorologi, Klimatologi dan Geofisika (BMKG) Kota Batam. Metode perhitungan dengan menggunakan curah hujan andalan 80\% berdasarkan curah hujan tahun 2010-2019 dan luas atap untuk tipe rumah 120/162 membutuhkan tanki dengan volume $10,45 \mathrm{~m}^{3}$, tipe rumah 103/120 membutuhkan tanki dengan volume $9,72 \mathrm{~m}^{3}$, tipe rumah 78/105 membutuhkan tanki dengan volume $9,00 \mathrm{~m}^{3}$ dan tipe rumah $50 / 90$ membutuhkan tanki dengan volume $8,79 \mathrm{~m}^{3}$. Penerapan system ini dapat menghemat penggunaan air sebesar 7,344 m³/bulan dan Rp 705.024/tahun.
\end{abstract}

Kata kunci :rainwater tank, perumahan, banjir, air hujan.

\begin{abstract}
The development of residents in the city of Batam resulted in an increase in the frequency of floods. This research aims to know the planning of rainwater tanks and the amount of water and costs saved by rainwater tank system for Citra Indah residential area, Batam Center. This study analyzed the tank needs needed for 4 types of houses in Citra Indah housing estate. Housing data obtained from PT Bangun Arsikon Batindo and rainfall data from the Bureau of Meteorology, Climatology and Geophysics (BMKG) Batam City. The method of calculation by using the mainstay rainfall $80 \%$ based on rainfall in 2010-2019 and the area of the roof of the house as the area of arrest. The results of the analysis of the application of rainwater tank system in Citra Indah housing, for 120/162 house type requires tank with volume $10.45 \mathrm{~m}^{3}$, house type 103/120 requires tank with volume $9.72 \mathrm{~m}^{3}$, house type $78 / 105$ requires tank with volume $9.00 \mathrm{~m}^{3}$ and house type $50 / 90$ requires tank with volume $8.79 \mathrm{~m}^{3}$. The implementation of the system can save water usage by 7,344 $\mathrm{m}^{3} /$ month and save costs of Rp 705,024/year.
\end{abstract}

Keywords: rainwater tank, residential, flood, rainwater. 


\section{PENDAHULUAN}

Kota - kota besar di Indonesia berkembang semakin cepat seiring berjalannya waktu. Perkembangan penduduk juga meningkat secara cepat, sehingga penataan kota juga harus menyesuaikan. Setiap kota harus bisa memenuhi kebutuhan masyarakatnya dalam menyediakan tempat tinggal maupun lahan yang cukup untuk masyarakatnya dalam membangun fasilitas umum hingga drainase dan perpipaan kota. Drainase merupakan salah satu aset kota yang penting dalam menjaga kenyamanan dan kesehatan penduduknya. Perencanaan drainase yang baik dimulai dari perumahan kecil hingga industri dan kemudian ke pipa utama pemerintah dan berakhir ketitik pembuangan yang besar.

Beberapa kota di Indonesia mengalami masalah banjir akibat dari perencanaan drainase yang kurang tepat dan juga pendistribusian air bersih tidak mencukupi kebutuhan penduduknya. Banjir yang terjadi di Indonesia pada umumnya terjadi akibat dari sampah - sampah padat yang masuk ke saluran drainase yang megakibatkan terhambatnya aliran air pada saluran. Banjir juga terjadi akibat perencanaan drainase yang kurang tepat dan juga debit penyaluran air dari masyarakat yang tidak dikontrol oleh pemerintah daerah masing-masing, sehingga air akan meluap ke jalan dan berdampak pada masyarakat sekitar. Air yang meluap pada saat banjir, bukan hanya air bersih dari air hujan, melainkan air yang tercampur dengan unsur kimia lainnya yang dapat mengganggu kesehatan dan kenyamanan masyarakat. Batam merupakan salah satu kota besar yang mengalami masalah banjir akibat dari musim hujan, salah satu daerah yang terdampak adalah kawasan J. Inersia 13(1)31-40
Perumahan Citra Indah, Batam Center. Perumahan ini terletak di Teluk Tering, kota Batam. Luas kawasan perumahan sekitar 4,9 ha dan terdiri dari 223 rumah. Kawasan banjir di perumahan Citra Indah ini terjadi akibat perbedaan elevasi antara Blok B, C, D, F dan Blok E, sehingga air dari Blok B, D, F, G mengalir menuju kawasan Blok E. Selain itu, saluran drainase yang ada kurang besar untuk meyalurkan air hujan yang turun, sehingga air meluap dari saluran pada saat hujan deras. Hasil penelitian sebelumnya menyebutkan bahwa metode rainwater harvesting dapat menghemat penggunaan air sekitar 52\% dari total kebutuhan serta dapat mengurangi volume limpasan (Pratiwi, 2016). Metode rainwater tank merupakan salah satu upaya penanganan dalam memperlambat aliran limpasan air hujan dan mengendalikan air agar dapat tertampung kedalam tank. Oleh sebab itu, diperlukan adanya penelitian di Kawasan Perumahan Citra Indah, Batam Center setelah dilakukan observasi langsung terdapat genangan bahkan banjir kecil di lokasi tersebut. Rainwater tank dikaji sebagai salah satu alternatif untuk menangani banyaknya limpasan dan terjadinya genangan di daerah yang elevasinya lebih rendah dan menjadikannya sebagai sumber cadangan air bersih untuk masyarakat.

\section{Kebutuhan Air}

Air merupakan elemen penting dalam kebutuhan hidup manusia yang memiliki fungsi penting untuk keberlangsungan hidup. Air dibutuhkan untuk memenuhi kebutuhan cairan tubuh dan juga untuk utilitas kebutuhan sehari - hari seperti memasak, mandi dan cucian (Pawenang, 2012). 
Kebutuhan air untuk setiap penduduk sangat penting dan harus dipertimbangkan oleh lembaga atau badan yang bertanggung jawab atas penyediaan air bersih untuk masyarakat, seperti PDAM dan ATB yang ada di kota Batam. SNI 19-6728.1-2002 menyebutkan tentang. Sumber Daya Air Spasial dan SNI 03-7065-2005 tentang Tata Cara Perencanaan Sistem Plambing. Kebutuhan air di daerah perkotaan mencapai 120 L/hari/orang, sedangkan untuk daerah pedesaan adalah 60L/hari/orang. Gambar 1 memperlihatkan penggunaan air bersih untuk rumah tangga di Indonesia di tahun 2019.

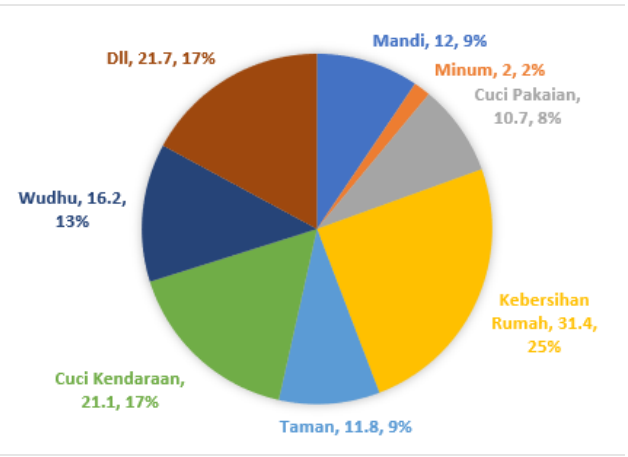

Gambar 1.Persentase kebutuhan air di Indonesia tahun 2019 (Rustan,dkk 2019)

Gambar 1 memperlihatkan kebutuhan air untuk rumah tangga di Indonesia paling banyak diperlukan untuk kebersihan rumah, cuci kendaraan, dan irigasi taman. Apabila air untuk irigasi taman, cuci kendaraan dapat digantikan dengan cadangan air dari rainwater tank maka dapat dihemat 32,9L/hari.

\section{Usaha Konservasi Air}

Konservasi air dilakukan dengan tujuan utama untuk memastikan ketersediaan air dalam kualitas dan kuantitas yang cukup untuk memenuhi kebutuhan masyrakat untuk sekarang maupun masa depan. Upaya konservasi air (Anonim, 2017) dapat dilakukan dengan 5 cara yaitu:

J. Inersia 13(1)31-40 a. Mempertahankan daerah tangkapan air dengan runoff dan debit yang sesuai

b. Kontrol terhadap pemakaian sumber air, dapat berupa perizinan atau kriteria penggunaan sumber air hingga larangan untuk penggunaan

c. Penataan sarana dan prasarana sanitasi, terutama untuk air limbah dan air kotor atau persampahan

d. Perlindungan sumber muara air, seperti pertimbangan pemanfaatan lahan di sekitar sumber air, terutama di daerah hulu

e. Rehabilitas lahan pertanian dan hutanAnda boleh menggunakan penomoran bertingkat dengan batasan satu tingkat.

\section{Rainwater Harvesting}

Rainwater harvesting dapat dijadikan sumber dari air bersih (yang tidak dapat dikonsumsi) dan digunakan untuk utilitas dan keperluan lainnya yang tidak memerlukan air yang dapat dikonsumsi, seperti air yang digunakan untuk mandi, cuci baju bahkan mobil, keperluan WC atau toilet hingga untuk irigasi (tanaman atau kebun).

Inggris meruapakan salah satu negara yang sudah menerapkan sistem pemanenan air hujan sejak tahun 1999, dan merupakan salah satu regulasi dan peraturan yang diakui dan dijalankan oleh sebagian daerah, karena pada umumnya setiap daerah mempunyai peraturan dan sistem pemanenan air hujan yang berbeda. Dalam sebuah penelitian membuktikan bahwa $62 \%$ dari sample pelanggan yang menerapkan sistem rainwater harvesting menggunakan air yang dipanen dapat digunakan untuk irigasi (untuk tumbuhan, bunga dan halaman). Selain untuk irigasi, sistem ini mengurangi biaya air yang harus dibayar 
setiap bulan dan mengurangi permintaan kebutuhan air, sehingga mengurangi pembebanan pemerintah dalam penyediaan air bersih(Rustan dkk, 2019). Australia merupakan salah satu negara yang menerapkan sistem rainwater harvesting terutama di daerah New South Wales. Setiap rumah wajib memiliki sistem pemanenan air hujan yang berfungsi sebagai sumber cadangan air alternatif dan juga mengontrol debit air yang akan mengalir keluar saluran rumah, dengan demikian, drainase dan saluran pembuangan akan terkendali dan tidak akan meluap karena setiap daerah sudah menerapkan peraturan dan regulasi masingmasing untuk persyaratan sistem rainwater harvesting.

Indonesia sudah mengenal sistem pemanenan air hujan sejak awal tahun 2000an, akan tetapi untuk peraturan dan kewajiban untuk menerapkan sistem ini masih belum ditegaskan sehingga kebutuhan air di Indonesia semakin meningkat karena perkembangan penduduk. Selain dari penggunaan tanki untuk pemanen air hujan, di Indonesia juga mengenal sumur resapan yang ditunjukkan pada Gambar 2.

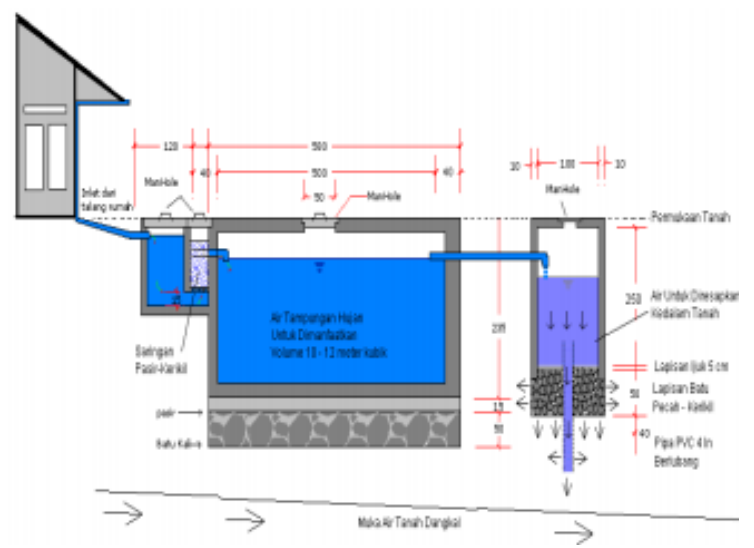

Gambar 2.Kombinasi Sistem Pemanenan Air Hujan dan Sumur Resapan (Herlambang, 2010)
Penelitian tentang rainwater harvesting yaitu perancangan sistem rainwater harvesting di Hotel Novotel Yogyakarta menghasilkan perhitungan sistem rainwater harvestingyang dapat menampung air sebanyak 478.820 liter/bulan dan 5.745.809 liter/tahun. Apabila pada musim hujan pada daerah tersebut, air yang terkumpul mencapai $21 \%$ dari total kebutuhan air dalam waktu satu bulan(Fathi dkk, 2014).. Penelitian tentang pemanfaatan air hujan juga dilakukan untuk kebutuhan pertamanan dengan Metode Penampungan Air Hujan untuk Pertamanan dan Toilet Gedung IV Fakultas Teknik Universitas Sebelas Maret, (Qomariyah, dkk 2016). Analisa intensitas air hujan yang terjadi di daerah kampus dan perancangan penampungan air untuk memenuhi kebutuhan pertanaman dan toilet menghasilkan perhitungan yang menunjukkan penghematan sekitar 58-65\%. Penggunaan air dari Perusahaan Daerah Air Minum dengan volume tanki yang diperlukan berkisar antara 40-65 $\mathrm{m}^{3}$ tergantung luas tanah dan luas atap setiap rumah (Elgara dkk,2016). Hasil penelitian lainnya yang dilakukan di Rusunawa Semanggi Surakarta dengan menggunakan data hujan selama 10 tahun menunjukkan air hujan yang dapat di tampung dari atap gedung sebanyak $1.226 \mathrm{~m}^{3} /$ tahun dengan penghematan biaya air sekitar 551.763 rupiah/tahun. Penerapan sistem rainwater harvesting juga dilakukan di kawasan perumahan G-land Padalarang, disimpulkan terdapat intensitas hujan sebesar 2.929 $\mathrm{mm} /$ tahun dan untuk daerah penangkapan sebesar $66 \mathrm{~m}^{2}$ dapat memanen sebanyak 173.983 liter air/tahun setara dengan menghemat air sebanyak 52\% dari total kebutuhan(Pratiwi dan Permana, 2016). 


\section{Rainwater Tank}

Rainwater tank merupakan salah satu alat yang dijadikan sebagai tempat pemanenan air hujan. Selain dari harganya yang lebih terjangkau, rainwater tank bersifat portable atau dapat dipindah-pindahkan. Rainwater tank dapat menyediakan air bersifat alami, bening, dan tidak berbau dan dapat digunakan untuk banyak kebutuhan properti. Di beberapa daerah pedesaan Australia, rainwater tank menjadi sumber air yang lebih andal dan terjangkau (Sharma dkk, 2016).

Air yang ditampung rainwater tank diperoleh dari air hujan yang jatuh ke atap rumah dan disalurkan ke dalam tanki melalui box gutter atau eaves gutter dan di Indonesia lebih di kenal dengan talang air, air kemudian akan disalurkan ke pipa ke bawah dan naik ke rainwater tank dengan prinsip tekanan air dalam pipa yang akan mendorong air kebawah dan naik dan masuk ke dalam tanki. Gambar 3 menunjukkan proses aliran air dari atap menuju rainwater tank dan juga bagianbagiannya.

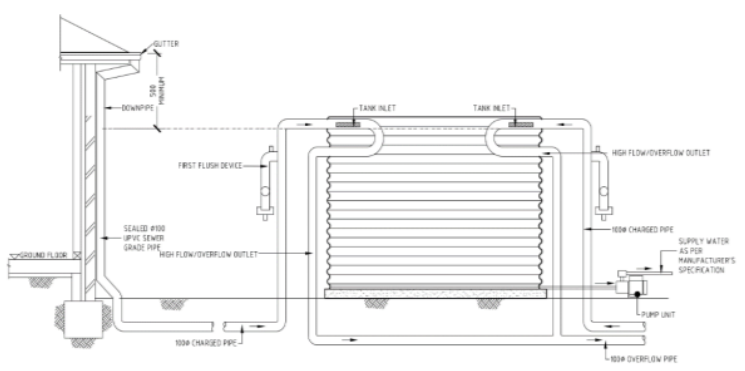

Gambar 3. Sistem kerja rainwater tank (Intrax Consulting Engineers)

\section{Curah Hujan}

Curah hujan merupakan kedalaman air hujan yang terjadi dalam kurun waktu yang ditentukan (Maharjono dan Qomariyah, 2017). Curah hujan harian merupakan curah

J. Inersia 13(1)31-40 hujan yang tercatat pada stasiun pengamat hujan selama 24 jam; curah hujan bulanan merupakan curah hujan harian yang tercatat selama satu bulan di stasiun pengamat hujan ; curah hujan tahunan merupakan curah hujan bulanan yang tercatat selama satu tahun di stasiun pengamat hujan. Data curah hujan kota Batam ada di Stasiun Curah Hujan Hang Nadim Batam. Intensitas curah hujan dapat dihitung dengan rumus Mononobe yang ditunjukan dalam Persamaan (1) :

$$
I=\left[\frac{R_{24}}{24}\right]\left[\frac{24}{t_{c}}\right]^{2 / 3}
$$

Dengan :

$\mathrm{I}=$ Intensitas Curah hujan ( $\mathrm{mm} / \mathrm{jam})$

tc $=$ Waktu konsentrasi (jam /menit)

$\mathrm{R}_{24}=$ Curah hujan harian maksimum tahunan

\section{Curah HujanAndalan}

Curah hujan andalan atau curah hujan efektif dihitung dengan peringkat curah hujan rerata tahunan yang diurutkan dari nilai tertinggi hingga nilai terendah (Maharjono, 2017). Kemudian dihitung dengan rumus probabilitas atau peluang dengan Persamaan (2)

$$
\text { Probabilitas }(\%)=\frac{m}{(n+1)} \cdot 100 \%
$$

Dengan:

$\mathrm{m}=$ urutan ke- $\mathrm{m}$ (dari paling kecil)

$\mathrm{n}=$ jumlah data

\section{Volume Ketersediaan Air Hujan}

Volume ketersediaan air hujan dihitung berdasarkan jumlah air hujan yang diterima dari atap bangunan dengan rumus yang ditetapkan dalam Permen PU tahun 2009 yang ditunjukkan pada Persamaan (3) .

$$
V=R \cdot A \cdot k
$$

Dengan:

$\mathrm{V}=$ volume air atap bangunan $\left(\mathrm{m}^{3} /\right.$ bulan $)$

$\mathrm{R}=$ Curah hujan per bulan( $\mathrm{m} / \mathrm{bulan}$ ) 
$\mathrm{A}=$ Luas atap bangunan $\left(\mathrm{m}^{2}\right)$

$\mathrm{K}=$ koefisien limpasan atau runoff

\section{METODE PENELITIAN}

Penelitian ini berlokasi di Jl H. Fisabilillah, Komplek Perumahan Citra Indah 1, Batam Center, Batam, Kepulauan Riau, Indonesia. Data yang digunakan di dalam penelitian ini adalah berupa data primer yaitu observasi lokasi, jenis, dan kondisi perumahan serta juga permasalahan yang terdapat di kawasanperumahan. Data yang digunakan dapat dilihat pada Tabel1

Tabel1 Data penelitian

\begin{tabular}{cllr}
\hline $\mathbf{N}$ & \multicolumn{1}{c}{ Data Primer } & \multicolumn{2}{c}{ Data Sekunder } \\
o & & Curah Hujan 10 \\
\hline 1 & Jbservasi: & tahun & (sumber: \\
& - Lokasi & - Jenis\&kondisiperu \\
mahan & BMKG) & \\
& & & \\
2 & & Data perumahan \\
& & Citra r Indah \\
& & (Sumber: PT. & PangunArsikonBat \\
& & indo) \\
\hline
\end{tabular}

HASIL DAN PEMBAHASAN

PerhitunganKebutuhan Air
Kebutuhan air yang ditentukan dalam Standar Nasional Indonesia 19-6728.1-2002 merupakan 120L/penghuni/hari, yang dibagi menjadi beberapa kategori pemakaian.

Kebutuhan air bersih yang dapat digantikan dengan air hujan ini berdasarkan Gambar 1 yaitu:

a. Irigasi Taman $=\quad=10,8 \mathrm{~L}$

b. Cuci Kendaraan $=20,4 \mathrm{~L}$

c. Kebersihan Rumah $=30,0 \mathrm{~L}$

Dengan mengasumsikan satu rumah terdiri dari 4 penghuni, maka kebutuhan air /hari/rumah $=(10,8+20,4+30,0) \mathrm{L}$ x $4=$ 244,8 L/rumah $\quad x \quad 30$ hari $=7.344$ L/rumah/bulan $=7,344 \mathrm{~m}^{3}$.

\section{Perhitungan Curah HujanAndalan}

Curah hujan andalan digunakan untuk menghitung kebutuhan besarnya ukuran tanki untuk setiap tipe rumah. Perhitungan curah hujan andalan dengan data curah hujan bulanan yang diperoleh dari Badan Meteologi, Klimatologi dan Geofisika stasiun Hang Nadim Batam yang dapat dilihat pada Tabel 2

Tabel 2 Data curah hujan rata-rata bulanan (mm)

\begin{tabular}{|c|c|c|c|c|c|c|c|c|c|c|c|c|}
\hline \multirow{2}{*}{ NO } & \multicolumn{12}{|c|}{ Bulan } \\
\hline & Jan & Feb & Mar & Apr & Mei & Jun & Jul & Ags & Sep & Okt & Nov & Des \\
\hline 1 & 30,3 & 45,2 & 310,6 & 215,3 & 164,4 & 191,7 & 215,5 & 122,6 & 286,3 & 165,8 & 221,5 & 88,8 \\
\hline 2 & 654 & 8,9 & 91,1 & 176,8 & 94,4 & 211,8 & 147,2 & 291,5 & 211,1 & 389,7 & 395,4 & 249,9 \\
\hline 3 & 0,3 & 4,5 & 112,1 & 40,9 & 112,5 & 8,2 & 12,7 & 0,1 & 5,8 & 15,8 & 8 & 24,7 \\
\hline 4 & 15,9 & 1,5 & 10,5 & 124,3 & 39,6 & 7 & 12,4 & 29,1 & 26,2 & 5,9 & 223,7 & 53,5 \\
\hline 5 & 6,3 & 0 & 57,7 & 171,5 & 263,4 & 194,9 & 249,7 & 229,2 & 162,3 & 19,9 & 222,1 & 298,5 \\
\hline 6 & 0 & 56,1 & 49,5 & 82,8 & 122,3 & 79,4 & 60,4 & 163,3 & 31,1 & 186,4 & 210,9 & 169,6 \\
\hline 7 & 0 & 308 & 10,2 & 61,5 & 144,8 & 184,1 & 264,5 & 153 & 97 & 209,4 & 451 & 0 \\
\hline 8 & 0 & 58,9 & 392 & 221,2 & 320,6 & 168,1 & 63,1 & 321,6 & 200,1 & 184,7 & 488,1 & 168,7 \\
\hline 9 & 237,4 & 9,2 & 207 & 120,2 & 106,9 & 169,2 & 50 & 143,1 & 132,4 & 120 & 398 & 188,8 \\
\hline 10 & 192,6 & 20,2 & 13,9 & 60,4 & 140,9 & 213,7 & 45,2 & 43,9 & 38,8 & 182,8 & 109 & 367,8 \\
\hline Rata & 113,6 & 51,2 & 125,4 & 127,4 & 150,9 & 142,8 & 112,0 & 149,7 & 119,1 & 148,0 & 272,7 & 161,0 \\
\hline -rata & 8 & 5 & 6 & 9 & 8 & 1 & 7 & 4 & 1 & 4 & 7 & 3 \\
\hline
\end{tabular}


Nilai probabilitas dihitung dengan

Persamaan(2):

Probabilitas $(\%)=\frac{m}{(n+1)} \cdot 100 \%$

$\mathrm{P}_{1}=\frac{1}{(10+1)} \cdot 100 \%=9,09 \%$

$\mathrm{P}_{2}=\frac{2}{(10+1)} \cdot 100 \%=18,18 \%$
$\mathrm{P}_{3}=\frac{3}{(10+1)} \cdot 100 \%=27,27 \%$

$\mathrm{P}_{4}=\frac{4}{(10+1)} \cdot 100 \%=36,36 \%$

Hasil rekapitulasi perhitungan probabilitas diurutkan dari curah hujan tertinggi hingga terendah dapat dilihat di Tabel 3.

Tabel 3. Curah hujan andalan bulanan $80 \%$ (mm)

\begin{tabular}{|c|c|c|c|c|c|c|c|c|c|c|c|c|c|}
\hline \multirow{2}{*}{ No } & \multicolumn{12}{|c|}{ Bulan } & \multirow{2}{*}{$\begin{array}{c}\text { Andalan } \\
\%\end{array}$} \\
\hline & Jan & Feb & Mar & Apr & Mei & Jun & Jul & Ags & Sep & Okt & Nov & Des & \\
\hline 1 & 654 & 308 & 392 & 221,2 & 320,6 & 213,7 & 264,5 & 321,6 & 286,3 & 389,7 & 488,1 & 367,8 & 9,09 \\
\hline 2 & 237,4 & 58,9 & 310,6 & 215,3 & 263,4 & 211,8 & 249,7 & 291,5 & 211,1 & 209,4 & 451 & 298,5 & 18,18 \\
\hline 3 & 192,6 & 56,1 & 207 & 176,8 & 164,4 & 194,9 & 215,5 & 229,2 & 200,1 & 186,4 & 398 & 249,9 & 27,27 \\
\hline 4 & 30,3 & 45,2 & 112,1 & 171,5 & 144,8 & 191,7 & 147,2 & 163,3 & 162,3 & 184,7 & 395,4 & 188,8 & 36,36 \\
\hline 5 & 15,9 & 20,2 & 91,1 & 124,3 & 140,9 & 184,1 & 63,1 & 153 & 132,4 & 182,8 & 223,7 & 169,6 & 45,45 \\
\hline 6 & 6,3 & 9,2 & 57,7 & 120,2 & 122,3 & 169,2 & 60,4 & 143,1 & 97 & 165,8 & 222,1 & 168,7 & 54,55 \\
\hline 7 & 0,3 & 8,9 & 49,5 & 82,8 & 112,5 & 168,1 & 50 & 122,6 & 38,8 & 120 & 221,5 & 88,8 & 63,64 \\
\hline 8 & 0 & 4,5 & 13,9 & 61,5 & 106,9 & 79,4 & 45,2 & 43,9 & 31,1 & 19,9 & 210,9 & 53,5 & 72,73 \\
\hline $\mathbf{P}$ & 0 & 3,9 & 13,22 & 61,28 & 104,4 & 65,16 & 38,7 & 40,94 & 30,12 & 19,08 & 190,5 & 47,74 & 80,00 \\
\hline 9 & 0 & 1,5 & 10,5 & 60,4 & 94,4 & 8,2 & 12,7 & 29,1 & 26,2 & 15,8 & 109 & 24,7 & 81,82 \\
\hline 10 & 0 & 0 & 10,2 & 40,9 & 39,6 & 7 & 12,4 & 0,1 & 5,8 & 5,9 & 8 & 0 & 90,91 \\
\hline
\end{tabular}

Nilai peluang curah hujan $80 \%$ dihitung dengan interpolasi:

$\mathrm{P}_{\mathrm{Jan}, 80}=0 \mathrm{~mm}$

$\mathrm{P}_{\mathrm{Feb}, 80}=3,9 \mathrm{~mm}$

$\mathrm{P}_{\mathrm{Mar}, 80}=13,22 \mathrm{~mm}$

Nilai peluang untuk curah hujan bulan April hingga Desember dihitung menggunakan cara yang sama.

\section{Ketersediaan Air Hujan dan Kebutuhan Volume Tanki}

Volume ketersediaan air dihitung dengan cara perkalian antara luas atap dengan curah hujan andalan dengan koefisien runoff (digunakan nilai sebesar 0,75 untuk jenis lahan "multi-unit, gabung" berdasarkan nilai koefisien limpasan dengan metode rasional). Oleh karena terdapat 4 tipe rumah yang berbeda di kawasan perumahan ini, maka perhitungan di bagi berdasarkan tipe rumah. Perhitungan ketersediaan air hujan di tunjukkan pada Tabel 4. 
Tabel 4. Ketersediaan air hujan

\begin{tabular}{|c|c|c|c|c|c|c|c|c|}
\hline \multirow{3}{*}{ Bulan } & \multirow{2}{*}{\multicolumn{2}{|c|}{$\begin{array}{c}\text { Tipe } 120 / 162 \\
\text { Luas atap : } 94,5 \mathrm{~m}^{2}\end{array}$}} & \multirow{2}{*}{\multicolumn{2}{|c|}{$\begin{array}{c}\text { Tipe } 103 / 120 \\
\text { Luas atap : } 68 \mathrm{~m}^{2}\end{array}$}} & \multirow{2}{*}{\multicolumn{2}{|c|}{$\begin{array}{c}\text { Tipe } 78 / 105 \\
\text { Luas atap : } 63 \mathrm{~m}^{2}\end{array}$}} & \multirow{2}{*}{\multicolumn{2}{|c|}{$\begin{array}{c}\text { Tipe } 50 / 90 \\
\text { Luas atap : } 61,5 \mathrm{~m}^{2}\end{array}$}} \\
\hline & & & & & & & & \\
\hline & $\begin{array}{c}\mathrm{CH} \\
\text { Andalan } \\
80 \%\end{array}$ & $\begin{array}{l}\text { Vol. } \\
\text { Ketersediaan } \\
\text { Air Hujan }\end{array}$ & $\begin{array}{c}\mathrm{CH} \\
\text { Andala } \\
\text { n } 80 \%\end{array}$ & $\begin{array}{c}\text { Vol. } \\
\text { Ketersediaan } \\
\text { Air Hujan }\end{array}$ & $\begin{array}{c}\mathrm{CH} \\
\text { Andalan } \\
80 \%\end{array}$ & $\begin{array}{c}\text { Vol. } \\
\text { Ketersediaan } \\
\text { Air Hujan }\end{array}$ & $\begin{array}{c}\mathrm{CH} \\
\text { Andalan } \\
80 \%\end{array}$ & $\begin{array}{c}\text { Vol. } \\
\text { Ketersediaan Air } \\
\text { Hujan }\end{array}$ \\
\hline Jan & 0 & 0,00 & 0 & 0,00 & 0 & 0,00 & 0 & 0,00 \\
\hline Feb & 3,9 & 0,28 & 3,9 & 0,20 & 3,9 & 0,18 & 3,9 & 0,18 \\
\hline Mar & 13,22 & 0,94 & 13,22 & 0,67 & 13,22 & 0,62 & 13,22 & 0,61 \\
\hline Apr & 61,28 & 4,34 & 61,28 & 3,13 & 61,28 & 2,90 & 61,28 & 2,83 \\
\hline Mei & 104,4 & 7,40 & 104,4 & 5,32 & 104,4 & 4,93 & 104,4 & 4,82 \\
\hline Jun & 65,16 & 4,62 & 65,16 & 3,32 & 65,16 & 3,08 & 65,16 & 3,01 \\
\hline Jul & 38,7 & 2,74 & 38,7 & 1,97 & 38,7 & 1,83 & 38,7 & 1,79 \\
\hline Agst & 40,94 & 2,90 & 40,94 & 2,09 & 40,94 & 1,93 & 40,94 & 1,89 \\
\hline Sept & 30,12 & 2,13 & 30,12 & 1,54 & 30,12 & 1,42 & 30,12 & 1,39 \\
\hline Okt & 19,08 & 1,35 & 19,08 & 0,97 & 19,08 & 0,90 & 19,08 & 0,88 \\
\hline Nov & 190,52 & 13,50 & 190,52 & 9,72 & 190,52 & 9,00 & 190,52 & 8,79 \\
\hline Des & 47,74 & 3,38 & 47,74 & 2,43 & 47,74 & 2,26 & 47,74 & 2,20 \\
\hline
\end{tabular}

Berdasarkan tabel ketersediaan air hujan di atas, maka selanjutnya dapat dihitung volume ketersediaan air hujan dengan cara perkalian antara luas atap dengan curah hujan andalan setiap bulannya dengan koefisien run-off. Adapun luas atap ditentukan berdasarkan 4 tipe rumah yang ada. Berikut contoh perhitungan volume ketersediaan air tipe 120/162 di bulan Mei.

Ketersediaan air hujan $=94,5 \mathrm{~m}^{2} \times 104,4$ $\mathrm{mm} \times 0,75=7,40 \mathrm{~m}^{3}$.

Tabel 5. Volume ketersediaan air yang berlebih

\begin{tabular}{|c|c|c|c|c|c|}
\hline \multirow{3}{*}{ Bulan } & \multirow{3}{*}{$\begin{array}{l}\text { Kebutuhan } \\
\text { Air }\left(\mathrm{m}^{3}\right)\end{array}$} & Tipe 120/162 & Tipe $103 / 120$ & Tipe 78/105 & Tipe 50/90 \\
\hline & & Luas atap : $94,5 \mathrm{~m}^{2}$ & Luas atap : $68 \mathrm{~m}^{2}$ & Luas atap : $63 \mathrm{~m}^{2}$ & Luas atap : $61,5 \mathrm{~m}^{2}$ \\
\hline & & $\begin{array}{l}\text { Vol. Ketersediaan } \\
\text { Air Hujan }\left(\mathrm{m}^{3}\right)\end{array}$ & $\begin{array}{l}\text { Vol. Ketersediaan } \\
\text { Air Hujan }\left(\mathrm{m}^{3}\right)\end{array}$ & $\begin{array}{l}\text { Vol. Ketersediaan } \\
\text { Air Hujan }\left(\mathrm{m}^{3}\right)\end{array}$ & $\begin{array}{l}\text { Vol. Ketersediaan Air } \\
\text { Hujan }\left(\mathrm{m}^{3}\right)\end{array}$ \\
\hline Jan & 7,34 & 0,00 & 0,00 & 0,00 & 0,00 \\
\hline $\mathrm{Feb}$ & 7,34 & 0,28 & 0,20 & 0,18 & 0,18 \\
\hline Mar & 7,34 & 0,94 & 0,67 & 0,62 & 0,61 \\
\hline Apr & 7,34 & 4,34 & 3,13 & 2,90 & 2,83 \\
\hline Mei & 7,34 & 7,40 & 5,32 & 4,93 & 4,82 \\
\hline Jun & 7,34 & 4,62 & 3,32 & 3,08 & 3,01 \\
\hline Jul & 7,34 & 2,74 & 1,97 & 1,83 & 1,79 \\
\hline Agst & 7,34 & 2,90 & 2,09 & 1,93 & 1,89 \\
\hline Sept & 7,34 & 2,13 & 1,54 & 1,42 & 1,39 \\
\hline Okt & 7,34 & 1,35 & 0,97 & 0,90 & 0,88 \\
\hline Nov & 7,34 & 13,50 & 9,72 & 9,00 & 8,79 \\
\hline Des & 7,34 & 3,38 & 2,43 & 2,26 & 2,20 \\
\hline
\end{tabular}

hasil volume ketersediaan air dengan kebutuhan air yang telah dihitung dibandingkan yaitu sebesar $7.344 \mathrm{~L}$ atau $7,344 \mathrm{~m}^{3}$. volume yang berlebih adalah volume yang dapat dilakukan pemanenan air hujan. Volume ketersediaan air hujan berlebih yang dapat dipanen ditunjukkan pada Tabel 5. Berdasarkan volume tersebut, maka volume tanki dapat direncanakan sesuai dengan volume kelebihan air masing - masing tipe rumah. 


\section{Desain DimensiTanki}

Dimensi tanki rainwater tank untuk per tipe rumah dipilih berdasarkan ukuran tanki yang tersedia di Kingspan Water Pty Ltd, Dimensi tanki sesuai dengan tipe rumah adalah sebagaiberikut

a. Tipe $120 / 162$

Tiperumah 120/162 membutuhkan total $10,45 \mathrm{~m}^{3}$. Dimensi yang ideal untuk tipe rumah ini adalah 2 round water tank dengan diameter $1,9 \mathrm{~m}$ dan tinggi 1,86 $\mathrm{m}$. Tanki tersebut dapat menyediakan air untuk menyiram toilet sebanyak 1758 kali; 10 jam penyiraman (cucitangan). Luas lahan yang diperlukan untuk 2 tanki ini adalah $7,22 \mathrm{~m}^{2}$.

b. Tipe $103 / 120$

Tiperumah 103/120 membutuhkan total $9,72 \mathrm{~m}^{3}$. Dimensi yang ideal untuktiperumahiniadalah 2 round tank dengan diameter $1,9 \mathrm{~m}$ dan tinggi 1,715 $\mathrm{m}$. Tankitersebutdapatmenyediakan air untukmenyiram toilet sebanyak 1620 kali; 8 jam penyiraman (cucitangan). Luas lahan yang diperlukanuntuk 2 tankiiniadalah $7,22 \mathrm{~m}^{2}$.

c. Tipe $103 / 120$

Tiperumah 103/120 membutuhkan total $9,72 \mathrm{~m}^{3}$. Dimensi yang ideal untuk tipe rumah ini adalah 2 round tank dengan diameter $1,9 \mathrm{~m}$ dan tinggi $1,715 \mathrm{~m}$. Tanki tersebut dapat menyediakan air untuk menyiram toilet sebanyak 1620 kali; 8 jam penyiraman (cucitangan). Luas lahan yang diperlukan untuk 2 tanki ini adalah 7,22 $\mathrm{m}^{2}$.

d. Tipe $103 / 120$

Tiperumah 103/120 membutuhkan total $9,72 \mathrm{~m}^{3}$. Dimensi yang ideal untuk tipe rumah ini adalah 2 round tank dengan diameter $1,9 \mathrm{~m}$ dan tinggi $1,715 \mathrm{~m}$. Tanki tersebut dapat menyediakan air untuk menyiram toilet sebanyak 1620 kali; 8 jam penyiraman (cucitangan). Luas lahan yang diperlukan untuk 2 tanki ini adalah $7,22 \mathrm{~m}^{2}$.

Berikut ini contoh tanki produk dari Kingspan Water Pty Ltd yang dipasang di kawasan perumahan Australia.

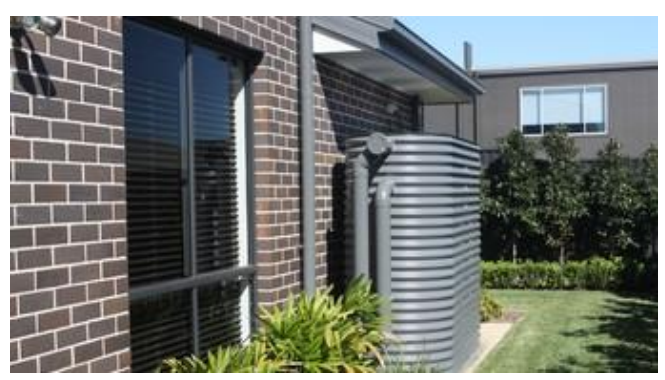

Gambar 5. Slimline Water Tank by Kingspan Pty Ltd

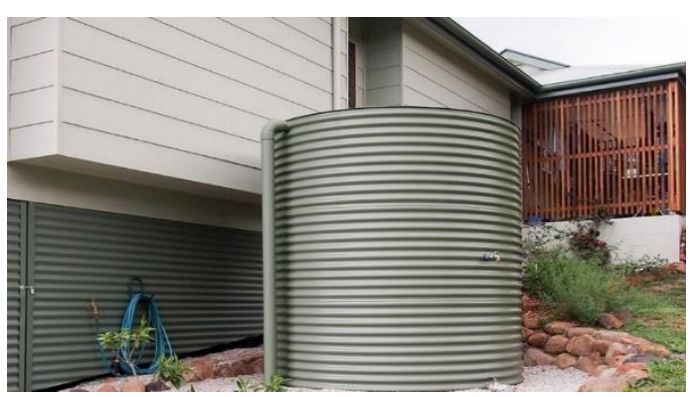

Gambar 6.Round Water Tank by Kingspan Pty Ltd

Untuk menerapkan system rain water tank tersebut maka dipilih jenis tanki yang tersedia di pasaran yang mendekati atau sama dengan volume terhitung dari masingmasing tipe rumah.

\section{Perhitungan Penghematan Biaya}

Biaya air per meter kubik diasumsikan sebesar Rp8.000/ $\mathrm{m}^{3}$, perhitungan penghematan biaya diluar biaya maintenance dan juga biaya $\mathrm{RAB}$ system rainwater tank. Penghematan biaya pertahun untuk penerapan system rainwater tank sebagai berikut:

$=7,344 \mathrm{~m}^{3} /$ bulan $\mathrm{x} 12$ bulan $\mathrm{xp} 8.000 / \mathrm{m}^{3}$

$=\operatorname{Rp} 705.024 /$ tahun 


\section{KESIMPULAN DAN SARAN}

Berdasarkan hasil analisa dan perhitungan kebutuhan volume rainwater tank yang di Perumahan Citra Indah, Batam Center, maka dapat disimpulkan dimensi rainwater tank yang ideal untuk tipe rumah 120/162 adalah 2 round tank x 1,9 m x 1,86 m; untuk tipe rumah 103/120 adalah 2 round tank x $1,9 \mathrm{~m} \times 1,715 \mathrm{~m}$; untuk tipe rumah 78/105 adalah 2 round tank $\mathrm{x}$ 1,8 $\mathrm{m} \times 1,785$ m; dan untuk tipe rumah 50/90 adalah 2 slimline tank $\times 2,9 \mathrm{~m} \times 1,0 \mathrm{~m} \times 1,635 \mathrm{~m}$. Dengan menerapkan system rainwater tank ini, diperkirakan dapat menghemat air sebanyak 7,344 $\mathrm{m}^{3} /$ bulan untuk setiap rumah dan Rp705.024/tahun.

\section{DAFTAR PUSTAKA}

Anonim (2017) Modul 3 tentang konservasi Sumber daya Air tahun 2017. Pusat Pendidikan dan Pelatihan, Kementrian PU dan Perumahan Rakyat

Badan Standarisasi Nasional [BSN]. (2002). SNI 19-6728.1. Penyusunan Neraca Sumber Daya -

Elgara, R., Qomariah, S. and Muttaqien, A. Y. (2016) 'Analisis dan Perencanaan PAH sebagai sumber air baku alternatif (studi kasus perumahan Nilagraha Pabelan Surakarta), e Jurnal Matriks

Fathi, A., Utami, S. and Budiarto, R. (2014) 'Perancangan Sistem Rain Water Harvesting, Studi Kasus: Hotel Novotel YOGYAKARTA',
Maharjono, S. Qomariyah, S. K. (2017) 'Analisis Dimensi Tanki PAH guna Pemanfaatan Air Hujan sebagai Sumber Air Cadangan untuk Bangunan Rusunawa (Studi Kasus: Rusunawa Semanggi, Surakarta)', e-JurnalMATRIKS TEKNIK SIPIL, pp. 258-264.

Pawenang, E. T. (2012) 'Pengelolaan Sumber Air Di Desa Jawesari Kecamatan Limbangan, Kabupaten Kendal', Jurnal Kesehatan Masyarakat, 8(1), pp. 17-22.

Pratiwi, V. and Permana, E. (2016) 'Analisis Penerapan Metode Rainwater Harvesting Pada Kawasan Perumahan G-Land Padalarang Untuk Menjaga Ketersediaan Air Tanah', Cantilever, 6(2), pp. 1-6.

Qomariyah, S., Solichin and R, A. P. (2016) 'Analisis Pemanfaatan Air Hujan Dengan Metode Penampungan Air Hujan Untuk Kebutuhan Pertamanan Dan Toilet Gedung IV Fakultas Teknik Universitas Sebelas Maret, Surakarta,

Rustan, F. R., Sriyani, R. and Talanipa, R. (2019) 'Analisis Pemakaian Air Bersih Rumah Tangga Warga Perumahan Bumi Mas Graha Asri Kota Kendari', Stabilita, 7(2), pp. 151-160.

Sharma, A. K. et al. (2016) 'Rainwater tanks in modern cities: A review of current practices and research', Journal of Water and Climate Change, 7(3), pp. 445-466. 